\title{
THE LIFE TABLE AND SOME BIOLOGICAL PARAMETERS OF POTATO TUBER MOTH (Phthorimaea operculella (Zeller) WHEN FEEDING ON DIFFERENT POTATO VARIETIES
}

\author{
OMER, H.I.H. ${ }^{1}$, M.A.A.M. EI-AW ${ }^{2}$, BADR.EL-SABAH.S.A.FETOH ${ }^{1}$, \\ K .A.A.DRAZ ${ }^{2}$ and ENAS M.A.GHAZALA ${ }^{1}$
}

1. Plant Protection Research Institute, A.R.C., Dokki .Giza .

2. Fac. of Agric . Damanhour University. Damanhour .

(Manuscript received 26 February 2012)

\begin{abstract}
Biological studies were carried out on the potato tuber moth Phthorimaea operculella (Zeller), when it fed on three different potato varieties: Kara,Spunta and Diamond to determine the ability of Ph. operculella to feed on , develop, fecundity and life table parameters as a sole food sources under laboratory conditions of $25 \pm 2^{\circ} \mathrm{C}$ and $65 \%$ R.H. obtained results and statistical analysis showed that developmental stages, fecundity and life table parameters of insect were affected by the tested different food types, where as, total immature stages lasted $(28.38 \pm 1.17)$, $(28.37 \pm 0.65)$ and $(24.50 \pm 0.87)$ days for female, when insect fed on the above mentioned diets respectively. Female oviposition period lasted ( 29,31 and 31 days ) which deposited eggs reached maximum to $(65.87,55.18$ and 68.44) eggs with daily average number of $(3.058,3.518$, 3.753) eggs/female when insect fed on the three potato varieties Kara, Spunta and Diamond respectively .
\end{abstract}

\section{INTRODUCTION}

Insect, mites and fungi infesting potato, stored grains and other products are responsible for causing both qualitative and quantitative losses especially when stored in moist and unhygienic conditions (Sinha et al., 1962). Potato tuber considered a biological systems with limited energy and are influenced by several a biotic factors. Potato are considered one of the most important sources of human food, therefore, it is necessary to study the pests which attack them causing much harm, which leading to decrease the amount of storage tubers. Developmental stages, fecundity, and life table parameters of $P h$. operculella were differed when varies kind of potato variety were used ( El- Saadany et al., 1998 and Debnath et al ., 2000 ). The present work aims to study the effect of different varities of potato tubers as a food Spunta , Kara and Diamond at $25 \pm 2^{\circ} \mathrm{C}$ and $65 \%$ R.H. on food ability , developing, fecundity and life table parameters of ph. operculla. 


\section{MATERIALS AND METHODS}

\section{Biological studies :}

Biological studies on Phthorimaea operculella (Zeller) were carried out under laboratory conditions in the Laboratory of Economic Entomology, Pest Control \& Environment Protection Department , Faculty of Agriculture, Damanhour. Each of life cycle of potato tuber moth and associated biological studies were investigated.

\section{Rearing Technique :}

Infested tubers of three potato varieties were collected from potato fields at harvesting time and kept in the laboratory as a stock culture. The three potato varieties namely Spunta, Kara and Dimaond were tested. The infested tubers of every variety were placed in large woody cage and provided with fresh and uninfested tubers. The cage dimensions were $30 \times 30 \times 30 \mathrm{~cm}$.

Sides of the cage were covered with white muslin cloth except the frontal side, which has a sleeve opening, for daily examination, and woody bottom. The cages were furnished with paper and sand . The newly emerged moth were collected, sexed then divided into groups ( $q: \hat{)}$ ) of 10 cuples in oviposition glass jar in the same day of adult emergence. These glass jars were coated insidely with white cylindrical paper as an oviposition site. The top of the jars were covered with muslin cloth fixed with rubberband. A piece of cotton soaked in $10 \%$ honey solution was provided as of food for the moth.. These jars were investigated daily to replace the cylindrical papers with another to count and record the number of eggs.

\section{Evaluating the effect of potato varieties host :}

Laboratory experiments were conducted under control conditions $\left(25^{\circ} \mathrm{C} \&\right.$ $65 \% \mathrm{RH}$ ) in an incubator. The newly deposited eggs were collected daily and divided into four groups in plastic cups, (100 eggs / replicate) and kept under the above mentioned controled conditions.

The eggs were investigated daily until hatching. Percent of the hatched egg hatching and incubation periods of eggs were recorded. Newly hatched larvae were picked up from cups by using fine brush then transferred to four plastic jars, which were furnished with paper and freshly slices of the potato variety for feeding larvae. Then the plastic jars were covered with pieces of cloth and kept in incubator under controlled conditions. Potatoes slices were replaced daily by fresh ones until pupation time. Newly formed pupae were collected and weighted in the same day of pupation, then placed in glass test tubes covered with cotton pieces. Pupae were investigated until adult emergence. The following biological parameters were investigated: larval duration, percent of larval mortality, percent of pupation, pupal duration and percent 
of adult emergence. The newly emerged moths were collected, sexed and confined in groups of cuples ( $q$ and $\delta^{1}$ ) at $1^{\text {st }}$ day of eclosion in glass jars, supplied with cylindrical white paper as an oviposition site. Eggs were collected daily, counted and placed in plastic cups under controlled conditions until hatching. The adults of both sexes were left for mating and to deposit their eggs until death. Data of adult stage included adult longevity, female fecundity [total number of eggs $\backslash$ female ] and egg fertility (hatchability percentage of eggs) were recorded.

\section{Life table parameters :}

Life table formula was applied according to Birch (1948) and Bries,D.T. (1980) . From this method, it could be possible to calculate generation time, fecundity, survival rate, net reproductive rate, intrinsic rate of increase, finite rate of increase, and population doubling time. This method based on the date obtained from the effect of different tested potato varieties .

\section{Fecundity and longevity of mated adult females :}

Newly emerged moths collected from each of the tested varieties then sexed in groups of couples $(q: \hat{)})$ in glass jars about 9-10 replicates in the same day of emergence were used for mating and followed the same technique as mentioned above. Other virgin females were put in glass jars as unmated females. These jars which contain mated females were investigated daily to count the number of eggs deposited on white cylinder paper, exchanged daily by another. Daily examination routine was conducted until moth death in all replicates.

\section{RESULTS AND DISCUSSION}

The study was conducted under laboratory conditions $\left(25 \neq 2^{\circ} \mathrm{C}\right.$ and 65 $\%$ R.H. ) to evaluate the different biological developmental stages, life table parameters, some biological features and biological parameter of adult females of potato tuber moth, Phthorimaea operculella (Zeller) (Lepidoptera : Gelechidae) when fed on three potato varieties namely (Kara, Spunta , and Diamond).

\section{Life table parameters :}

The effect of different potato varieties ( Kara, Spunta and Diamond) on the life table parameters of $P h$. operculella (Zeller) when reared under laboratory conditions of $25^{\circ} \mathrm{C}$ and $65 \%$ R.H was shown in Table (1) Fig (1). Obtained data revealed that the total life span (L) showed 64, 59 and 56 days when insect fed on the previously mentioned diets respectively while the female fecundity ( $\mathrm{mx}$ ) was 3.058, 3.518 and $3.753 \mathrm{egg}$ ( female) at the same trend, while the net reproductive rate( $R^{\circ}$ )was $19.633,8.697$ and 18.815 egg / female ) when individuals were Fed on 
the same dietes. Generation duration (Gt) was $34.1,33.508$ and 30.241 days, while the Intrinsic rate of increase ( $\mathrm{rm}$ ) was $0.25,0.113$ and 0.270 individual / female, and finite rate of increase $(\lambda)$ was $1.284,1.120$ and 1.310 individual / female) at the same pattern . Population doubling time (Dt) was 3.477, 7.691 and 3.219 days at the same pattern . These results are in agree with those obtained by Chi, H. (1988).

\section{Biological Features:}

Incubation period : As shown in Table (2) the incubation period of the insect female was significantly not affected by the type of the tested food at $25^{\circ} \mathrm{C}$. female incubation period durated 4 days at the same trend.

Larval Duration: Female larval duration was affected by the different food types, thus, female larval duration decreased from $16.18 \neq 0.37$ day on Spunta variety to $15.76 \neq 1.49$ day on Kara variety and to $13.69 \neq 0.77$. These results concided with those obtained by Salas and Quiroga (1985) , Gamboa and Notz (1990), Singh et al, (1990), Debnath et al., (2000) , and Taha et.al.(2010).

Larval mortality: Statistical analysis of the obtained results Table (2) cleared that feeding on both Kara and Spon reduced larval mortality $(35.87 \neq 6.9 \%$ and $49.83 \neq$ $5.88 \%$ ) comparing with feeding on Diamond variety ( $34.68 \neq 6.88 \%$ ).

Pupal Duration: Pupal duration not affected when feed on both Kara and Spunta varieties

( $8.62 \neq 0.633$ and $8.19 \neq 0.550$ ) days, but pupal duration significantly decreased when feed on Diamond variety. This result agree with (Debnath et al., 2000).

Pupal Mortality: Pupal mortality statistically was not affected when feed on the three potato varieties. Pupal mortality was $30.7 \neq 9.74 \%, 41.38 \neq 5.59$ and $31.75 \neq$ $2.65 \%$ when insect fed on the previous mentioned foods.

Mean weight of pupae: As shown in Table (2) the mean weight of female pupae was significantly affected by the different food types at $25^{\circ} \mathrm{C}$. recording $8.80 \neq$ $0.32,9.98 \neq 0.55$ and $8.63 \neq 0.34 \mathrm{mg}$. while the mean weight of male pupae not affected by the different food types. The mean weight of male pupae was $10.09 \neq$ $0.81,11.09 \neq 0.25$ and $10.18 \neq 0.49 \mathrm{mg}$ respectively.

Adult Emergence \% : Adult emergence of male and female not affected by the different food types. The $\%$ adult emergence of adult male was $34.8 \neq 9.79,51.99 \neq$ 13.37 and $45.03 \neq 9.59$, while the $\%$ adult female was $55.2 \neq 9.79,48.01 \neq 13.37$ and $45.13 \neq 9.49$ when the insect fed on the previous mentioned food. Table( 2 )

Sex Ratio: Sex ratio not affected by different food types. The $\delta$ total was $0.666 \neq$ $0.145,0.480 \neq 0.134$ and $0.500 \neq 0.164$ when the insect fed on the previous mentioned food. 
Total Immature Period: Total immature stages stayed $28.38 \neq 1.17$ and $28.37 \neq$ 0.65 days without significant difference when fed on Kara and Spunta varieties, while for Diamond variety this period significantly lasted $24.50 \neq 0.87$ day. Thus, the total immature stages being shorter when the insect fed on Diamond varieties.

\section{Biological parameter of mated adult females Fecundity:}

Data in Table (2) Fig (2) showed that female fecundity of mated female was affected by the different potato varieties, thus, female fecundity decreased from 3.753 eggs on Diamond varieties to 3.518 eggs on Spunta varieties, and to 3.058 eggs on Kara varieties respectively. These results coincided with those obtained by El-Nagger et al., (1989)., Taha et al., (2004) .

Longevity: The obtained results cleared that feeding on Kara variety prolonged the longevity period of mated female (35 days) Table (3) fig (3) comparing with Diamond and Spunta varieties (31days).

Hatchability: The obtained data Table (3) revealed that the highest \% hatchability (68.44) was obtained when fed on Diamond variety followed by Kara variety (65.87) and Spunta varieties (55.18) respectively.

Fig 1. Duration of different stages of Ph.operculella when Fed on different potato varieties at $25^{\circ} \mathrm{c}$ and $65.00 \%$ R.H .

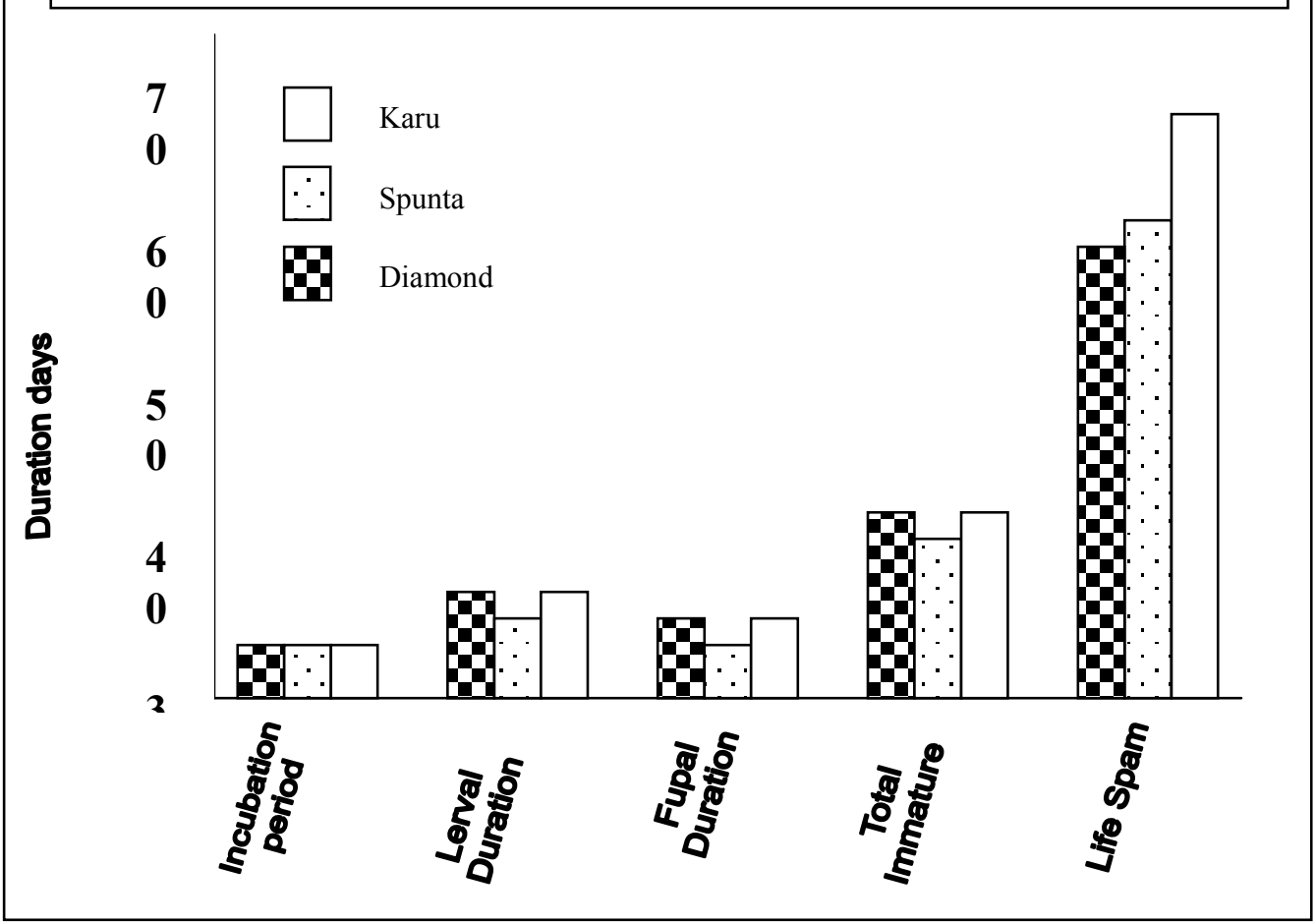



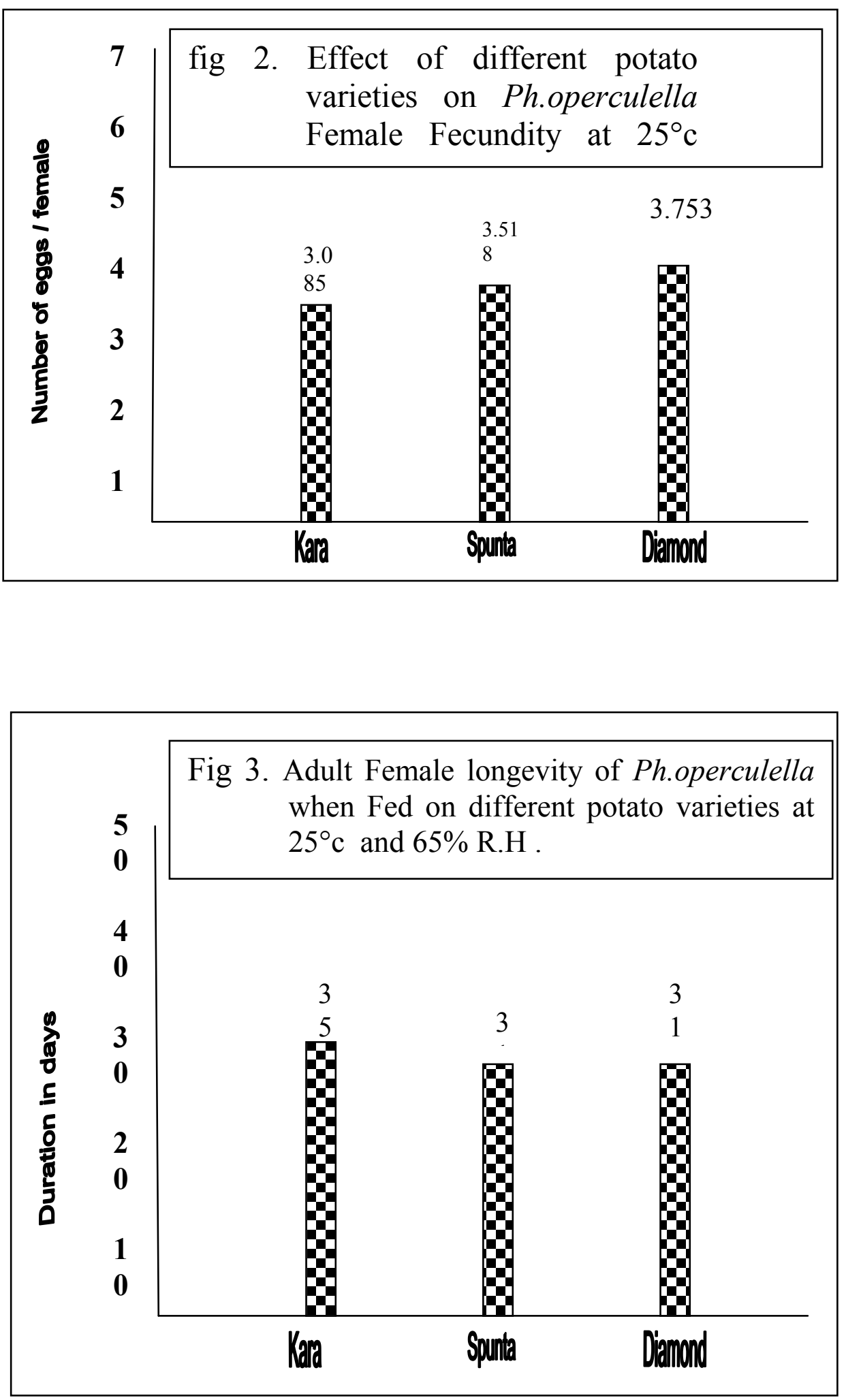
Table 1. Effect of different potato varieties on life table parameters of potato tuber moth Ph. operculella under laboratory conditions ( $25^{\circ} \mathrm{C}$ and 65 \%R.H.)

\begin{tabular}{|c|c|c|c|c|c|c|c|}
\hline $\begin{array}{c}\text { Life Table } \\
\text { parameters }\end{array}$ & $\begin{array}{l}\text { Total } \\
\text { span } \\
(\mathrm{L}) \\
\text { (days) }\end{array}$ & $\begin{array}{c}\text { Female } \\
\text { fecundity } \\
(\mathrm{mx}) \\
\text { (egg/ female }\end{array}$ & $\begin{array}{l}\text { Net } \\
\text { reproductive } \\
\text { rate }\left(R^{\circ}\right) \\
\text { (egg/ female }\end{array}$ & $\begin{array}{c}\text { Generation } \\
\text { duration (Gt) } \\
\text { (days) }\end{array}$ & $\begin{array}{c}\text { Intrinsic rate of } \\
\text { increase } \\
(\mathrm{rm}) \\
\text { (individual / female) }\end{array}$ & $\begin{array}{c}\text { Finite rate of } \\
\text { increase }(\lambda) \\
\text { (individual / } \\
\quad \text { female }\end{array}$ & $\begin{array}{c}\text { Population } \\
\text { doubling } \\
\text { time (Dt) } \\
\text { Days }\end{array}$ \\
\hline Kara & 64 & 3.058 & 19.633 & 34.100 & 0.250 & 1.284 & 3.477 \\
\hline Spunta & 59 & 3.518 & 8.697 & 33.508 & 0.113 & 1.120 & 7.691 \\
\hline Diamond & 56 & 3.753 & 18.815 & 30.241 & 0.270 & 1.310 & 3.219 \\
\hline
\end{tabular}


Table 2. Biological feature of larval and pupal stages of $P h$. operculella female when fed on different potato varieties under laboratory conditions at 25 ${ }^{\circ} \mathrm{C}$ and $65 \%$ R.H.

\begin{tabular}{|c|c|c|c|c|c|c|c|c|c|c|}
\hline \multirow{2}{*}{$\begin{array}{l}\text { Potato } \\
\text { varieties }\end{array}$} & \multirow[t]{2}{*}{$\begin{array}{l}\text { Larval } \\
\text { Duration } \\
\text { (Days } \pm S D \text { ) }\end{array}$} & \multirow[t]{2}{*}{$\begin{array}{l}\text { Larval } \\
\text { Mortality (\%) } \\
\pm \text { SD) }\end{array}$} & \multirow[t]{2}{*}{$\begin{array}{l}\text { Pupal } \\
\text { Duration } \\
\text { (Days } \pm \text { SD) }\end{array}$} & \multirow[t]{2}{*}{$\begin{array}{l}\text { Pupal Mortality } \\
(\%) \pm S D\end{array}$} & \multicolumn{2}{|c|}{$\begin{array}{l}\text { Mean weight of } \\
\text { Pupae(mg) } \\
\pm \text { SD }\end{array}$} & \multicolumn{2}{|c|}{$\begin{array}{l}\text { Adult Emergence } \\
(\%)\end{array}$} & \multirow[t]{2}{*}{$\begin{array}{l}\text { Sex Ratio } \\
\text { ( } \delta \text { :Total) }\end{array}$} & \multirow[t]{2}{*}{$\begin{array}{l}\text { Total immature } \\
\text { Period (Days) }\end{array}$} \\
\hline & & & & & $\Leftrightarrow \Leftrightarrow$ & q & 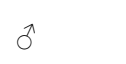 & q & & \\
\hline Kara & $\begin{array}{c}15.76 \\
\pm \\
1.49 \\
\end{array}$ & $\begin{array}{c}35.87 \\
\pm \\
6.90 \\
\end{array}$ & $\begin{array}{c}8.62 \\
\pm \\
0.633 \\
\end{array}$ & $\begin{array}{c}30.7 \\
\pm \\
9.74 \\
\end{array}$ & $\begin{array}{c}8.80 \\
\pm \\
0.32 \\
\end{array}$ & $\begin{array}{c}10.09 \\
\pm \\
0.81 \\
\end{array}$ & $\begin{array}{c}34.8 \\
\pm \\
9.79 \\
\end{array}$ & $\begin{array}{c}55.2 \\
\pm \\
9.79 \\
\end{array}$ & $\begin{array}{c}0.666 \\
\pm \\
0.145 \\
\end{array}$ & $\begin{array}{c}28.38 \\
\pm \\
1.17 \\
\end{array}$ \\
\hline Spunta & $\begin{array}{c}16.18 \\
\pm \\
0.37 \\
\end{array}$ & $\begin{array}{c}49.83 \\
\pm \\
5.88 \\
\end{array}$ & $\begin{array}{c}8.19 \\
\pm \\
0.550 \\
\end{array}$ & $\begin{array}{c}41.38 \\
\pm \\
5.59 \\
\end{array}$ & $\begin{array}{c}9.98 \\
\pm \\
0.55 \\
\end{array}$ & $\begin{array}{c}11.09 \\
\pm \\
0.25 \\
\end{array}$ & $\begin{array}{c}51.99 \\
\pm 13.37\end{array}$ & $\begin{array}{c}48.01 \\
\pm 13.37\end{array}$ & $\begin{array}{c}0.480 \\
\pm \\
0.134 \\
\end{array}$ & $\begin{array}{c}28.37 \\
\pm \\
0.65 \\
\end{array}$ \\
\hline Diamond & $\begin{array}{c}13.69 \\
\pm \\
0.77\end{array}$ & $\begin{array}{c}34.68 \\
\pm \\
6.88\end{array}$ & $\begin{array}{c}6.81 \\
\pm \\
0.380\end{array}$ & $\begin{array}{c}31.75 \\
\pm \\
2.65\end{array}$ & $\begin{array}{c}8.63 \\
\pm \\
0.34\end{array}$ & $\begin{array}{c}10.18 \\
\pm \\
0.49\end{array}$ & $\begin{array}{l}45.03 \\
\pm \\
9.59\end{array}$ & $\begin{array}{l}45.13 \\
\pm \\
9.49\end{array}$ & $\begin{array}{c}0.500 \\
\pm \\
0.164\end{array}$ & $\begin{array}{c}24.50 \\
\pm \\
0.87\end{array}$ \\
\hline Fvarieties L.S.D $(0.05)$ & $7.18 \quad 2.281$ & $6.54 \quad 15.135$ & $\begin{array}{l}12.74 \\
1.223\end{array}$ & $\begin{array}{c}- \\
\text { N.S. }\end{array}$ & $\begin{array}{c}11.84 \\
0.98\end{array}$ & - N.S. & - N.S. & - N.S. & $\overline{\text { N.S. }}$ & $\begin{array}{c}23.64 * * * \\
2.116\end{array}$ \\
\hline
\end{tabular}


Table 3. Adult female fecundity, longevity and $\%$ hatchability of Ph. operculella when fed on different potato varieties and reared under laboratory conditions $\left(25^{\circ} \mathrm{C}\right.$ and $65 \%$ R.H. )

\begin{tabular}{|c|c|c|}
\hline & Longevity (days) & Hatchability (\%) \\
\hline Kara & 29 & 65.87 \\
\hline Spunta & 31 & 55.18 \\
\hline Diamond & 31 & 68.44 \\
\hline
\end{tabular}




\section{REFERENCES}

1. Brich, L. C. 1948. The intrinsic rate of natural increase of an insect population . J. Anim. Ecol., 86 (5) : 15-26.

2. Bries, D. T. 1980. Characterizations of laboratory strains of the potato tuber moth Ph. operculella ( Lepidoptera : Gelechiidae). Bull.Ent. Res., 70 : 203- 212 .

3. Chi, H. 1988 . Life -table analysis incorporating both sexes and variable development rates among individuals. Environmental Entomology , 17 (1) : 2634.

4. Debnath, M. C., J. N. Khaund , B.K. Borah, P.C. Sarmah. 2000. Life table analysis of potato tuber moth, Phthorimaea operculella (Zeller) under laboratory condition.. Journal -of- Applied- Zoological- Researches. 11 (2-3) : 120- 123.

5. El- Naggar, M.E., H. A. Taha and F. M. Hoda. 1989. Biological studies on Rhizoglyphus ismaili (Astigmata : Acaridae) and the effect of types food on duration and fecundity . Bull.Zool. Soc. Egypt (38): 81-86.

6. El- Saadany, G.B., F.M. Mariy, M.A. Daoud and M. Ibrahim. 1998. Life table studies on potato tuber moth, ph. operculella. Zagazig J. Agric. Res., 25 (4) : $649-657$.

7. Gamboa, M. and A. Notz. 1990. Biology of Ph. operculella (Zeller) (Lepidoptera : Gelechiidae) in potatoes ( Solanum tuberosum ). Revista de la Facultad de Agronomia , Universidad Central de Venezuela , 16 (3-4) : 245- 257).

8. Salas, J. and B. Quiroga. 1985 . Biology of Phthorimaea operculella (Lepidoptera , Gelechiidae) the potato tuber moth . Agronomia- Tropical , 35: 4-6, 41- 49.

9. Singh, M.B., R.M. Bhagat and D.C. Sharma. 1990. Life history and host range of potato tuber moth Ph. operculella (Zeller). Himachal Journal of Agricultural Research , 16(1-2) : 59- 62.

10. Sinha, R.N., Liscombe and H. A. H. Wallance . 1962. Association of granary mites and seed borne fungi in stored grain Can. Entomol. 94(5) : 542- 555.

11. Taha, H. A. , K. S. Abou- El-Ela and M. A. El-Sanady. 2004 . Effect of food and temperature on developmental stages and fecundity of the grain mite Dermatophagoides farinae Hughes ( Acari: Acaridida: Pyroglyphidae). Egyptian Journal of Agric. Research. 82(3) : 1121-1126.

12. Taha, H.A. , Hanna I. Mahmoud, M. I. Hassan, Nahed R. Omar, and Heba M. Nasr. 2010. Effect of different food types on the biology, fecundity and life table parameters of the stored grain mite Gohieria fusca (OUD) ( Acari: Astigmata: Lapidophoridae). Egypt. J. Agric. Res., 88(1) . 
التفذية على أصناف مختلفة من البطاطس وعلاقتها ببعض المقاييس البيولوجية وجدول الحياة لفراشة درنات البطاطس (Phthorimaea operculella (Zeller) (Lepidoptera, Gelechidae)

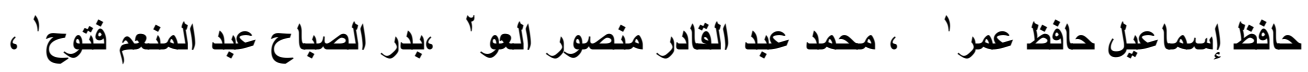

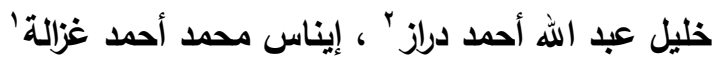

$$
\text { r- ا- دعه بحوث وقاية النباتات- قسم بحوث حشرات الخضر - مركز البحوث الزراعية -دقي-جيزة. }
$$

أجريت دراسات بيولوجية لفراثـة درنات البطاطس Phthorimaea operculella (Zeller) تحت

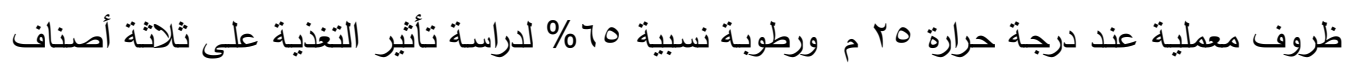

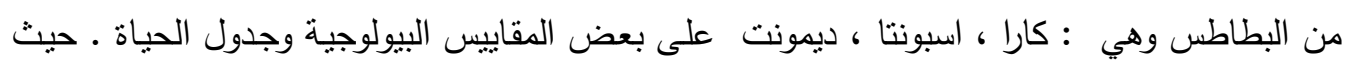

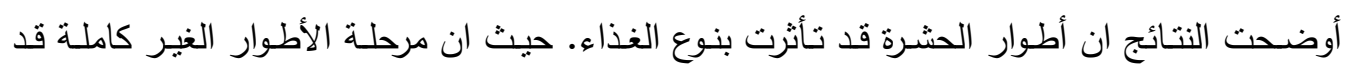

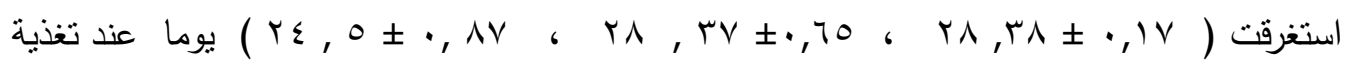

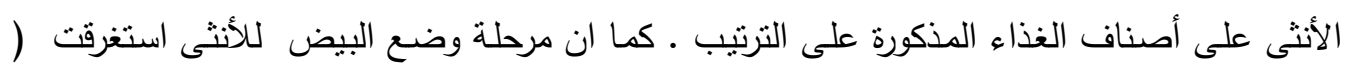

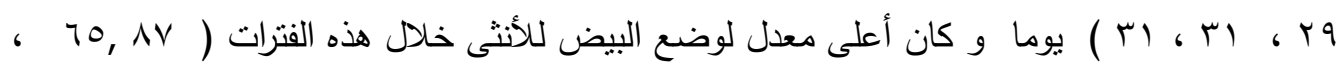
ع 11 على أصناف البطاطس كارا، اسبونتا ، ديمونت على الترتيب . 